\section{Sixth Grade Students' Skills of Using
Multiple Representations in Addition and \\ Sixth Grade Students' Skills of Using
Multiple Representations in Addition and Subtraction Operations in Fractions*}

\begin{tabular}{ll}
\hline Received: & 14 February 2018 \\
Revised: $\quad 20$ March 2018 \\
Accepted: $\quad 20$ March 2018 \\
ISSN: 1307-9298 \\
Copyright C IEJEE \\
www.iejee.com
\end{tabular}

DOI: 10.26822/iejee.2018438137

\begin{abstract}
The current study aims to show the transition skills of sixth grade students between the representations (numerical, model, number line and verbal) given in addition-subtraction operations in fractions and to analyse the ability of the students to construct each representation type. In this research, case study method was used in terms of the subject and process followed. The study group of the research is the sixth grade students of three middle schools in Kastamonu province placed in the northern part of Turkey. The research participants consisted of 59 students, 31 of which are male and 28 of which are female. Data collected through "Multiple Representations in Fraction Operations Test". According to research findings, it has been determined that the achievement of students in using different representations in operations with fractions is higher in addition operation compared to subtraction operation. In addition, it turns out that students are more successful in numerical-numerical, model-model, model-numerical, and numerical-model transitions compared to other transitions in both operation types. It was also found out that students fail in other representation types such as number line and verbal representation transition situations.
\end{abstract}

Keywords: Multiple representations; addition and subtraction of fractions; representation creation skill; transition among representations

\section{Introduction}

Most people define mathematics as a field consisting of abstract concepts, algorithms, and symbols without any connection with real world (e.g. Cramer, 2003). For this reason, researchers emphasize the necessity of teaching mathematics as an integrated concept and processing system based on certain patterns and associations that exist in the real world (Nair \& Pool, 1991; Resnick \& Ford, 1981). This necessity causes long debates in the need for using appropriate representations in teaching and learning of mathematics in terms of having complete understandings of mathematical concepts, expressing mathematical ideas and relationship between concepts (Duval, 2006; Goldin \& Shteingold, 2001). Moreover, taking advantage of different representations in the teaching of a mathematical concept and making transitions between different forms of representations are critical in terms of a complete internalization of mathematics. (Kaput, Blanton, \& Moreno, 2008; Lesh, 1999; National Council of Teachers of Mathematics [NCTM], 2000). Hence, the use of representations has been a crucial topic in learning of mathematics over the past three decades in standards of school mathematics for developing students' abilities to use appropriate representations and to make correct and robust translations among them (Ministry of National Education [MoNE, 2013]; National Council of Teachers of Mathematics [NCTM], 2000; Van de Walle, Karp, \& Bay-Williams, 2010). However, studies focusing on students' abilities in use of representations indicate that middle school students have inadequate knowledge and ability to construct appropriate representations and to transform from one representation to the others (Gagatsis \& Elia, 2004; Neria \& Amit, 2004).

Multiple representations can be defined as a process of vis- ualizing and concretizing abstract concepts or symbols in everyday life in general terms, as well as the definition of the relationship between objects or symbols in mathematics (Kaput, 1989). The theory of multiple representations in mathematics education has begun to gain importance with the studies of Dienes. Influenced by Piaget's theories and made studies with Bruner, Dienes called the concept of multiple representations as "Perceptual Diversity Principle." According to this principle, presenting a conceptual structure in multiple forms as perceptually identical as possible will make it easier for the student to have the mathematical significance of abstracting (Dienes, 1960). In this context, concepts should be able to be presented in different forms. Multiple representations and the learning relationship point to a learning environment with a particular focus on conceptual learning (Dufour-Janvier, Berdnarz, \& Belanger, 1987). In this context, mathematics teachers need to consider and effectively use multiple representations of information in verbal, numerical, visual graphical or numerical forms, with the support of developing technology, rather than using only intensive verbal and mathematical language.

Research on multiple representations in mathematics teaching has shown that using multiple representations helps students better understand and improve their problem solving performances (Ainsworth, Bibby, \& Wood, 1997; Akkuş-Çıkla, 2004; Moseley \& Brenner, 1997; Sert, 2007). If it is not possible to switch between different representations, it can be said that the mathematics cannot be understood at the conceptual level (Ainsworth, 1999; Van der Meij \& De Jong, 2006), When studies focusing on multiple representations are examined, it has been shown that the efforts of the students to determine the ability to switch between different representations are based on problem solving (Corter \& Zahrer, 2004;

\footnotetext{
"This study has been produced from the master's thesis referenced as "Kara, F. (2017). An investigation of sixth grade students' skills of using multiple representations in addition and subtraction of fractions. Unpublished master's thesis, Kastamonu University, Graduate School of Science."

a Fatma Kara, Graduate student at Kastamonu University, Faculty of Education, Department of Mathematics and Science Education, E-mail:fatmakara7581@gmail.com

${ }^{* * *}$ Corresponding author: Lutfi Incikabi, Kastamonu University, Faculty of Education, Department of Mathematics and Science Education, Kastamonu, Turkey. E-mail: lincikabi@kastamonu.edu
} 
İpek \& Okumuş, 2012; Lesh, Landau, \& Hamilton, 1983), algebraic expressions (Sert, 2007) and function (Baştürk, 2010). Moreover, some studies focused on the ability of students' and teachers' preferences for multiple representations (Ainsworth, 1999; Akkuş-Çıkla, 2004; Sert 2007). However, there has not been a detailed examination of the addition and subtraction operation of fractions between multiple representations and multiple representations.

In mathematics education context, worldwide research on students' understanding about fractions and fraction operations indicates that learning fractions is a complex and difficult process. The impediments in students' reasoning of fractions included factors such as an early emphasis on whole-numbers (e.g. Behr, Harel, Post \& Lesh, 1994) and insufficient abilities to transform between multiple representations (Tunç-Pekkan, 2015). On the other hand, it is claimed that even though students can easily carry out the algorithms with fractions, they do not understand the meanings of such algorithms (Mick \& Snicrope, 1989; Wearne-Hiebert \& Hiebert, 1983). Considering students difficulties and misconceptions about addition of fractions, researchers suggest using multiple representations in teaching and learning of fractions meaningfully in order to overcome students' difficulties and to develop their conceptual understanding of fractions (e.g. Alacacl, 2010; Tunç-Pekkan, 2015).

Studies about fractions generally focus on the problems that students have experienced in operations with fractions (Orhun, 2007; Soylu \& Soylu, 2005), the problems they have in creating different representations of fractions (Işık \& Kar, 2012; Pesen, 2008), the representation preferences that students use in fractions (Kılıç \& Özdaş, 2010), and the misconceptions they have about fractions (Biber, Tuna, \& Aktaş, 2013). However, no studies have been found that examine the preferences of students, achievement situations in their preferences and representation creation situations. Developments in the way students think about representation in mathematical learning have revealed the need for the use of multiple representations (Pape \& Tchoshanov, 2001). In this context, there are unanswered questions about the qualities of creating and using multiple representations, and the questions of this research are worth answering. Again, the results of this research are important for the review of classroom teaching. On the other hand, these research findings of this study are thought to contribute to the use of alternative pedagogical approaches to mathematics educators and researchers, and to investigate the effects of these approaches on classroom settings.

\section{Purpose of the research}

Among the purposes of this study are to show the transition skills of sixth grade students between the representations (numerical, model, number line and verbal) given in addition-subtraction operations in fractions and to analyze the ability of the students to construct each representation type.

\section{Problems of the research}

1) How are the transition skills of students between the multiple representations involved in the addition and subtraction operations in fractions?

2) How are the skills of the students to create different types of representations used in the addition and subtraction operations in fractions?

\section{Methodology}

In this research, case study method, which is one of the interactive patterns in the qualitative research approach, was used in terms of the subject and process followed. The case study is a method that allows the researcher to focus on a specific situation such as an event, a person or a group and investigate the situation in the cause-effect relation with the obtained data in more detail (Çepni, 2012). In the case study, in the questions of "How?" or/ and "Why?" are included in the research design and the case is examined in depth (Yıldırım \& Şimşek, 2013). In this study, the transitions of sixth graders were defined between the representations in the addition and subtraction of fractions according to the question of "How?". We also investigated the difficulties encountered in the process of creating each representation using the question "Why?".

\section{Study group}

The study group of the research is the sixth grade students of three middle schools in Kastamonu province placed in the northern part of Turkey. Purposeful (deliberate) sampling method was used to determine the participants (Yıldırım \& Şimşek, 2013). Criteria for determining grade level included curriculum coverage of the objectives regarding operations in fractions, and in this context, sixth grade students have been used as the targeted population. In determining the schools to be worked with, the provincial general achievement average was taken into account and three schools with average level of achievement were included in the study.

Initially, a total of 73 sixth grade students, 38 males and 35 females, participated in the research. However, as a result of the pre-evaluation of the application, it was determined that 14 students did not answer the questions at all and they were excluded from the further examination. Finally, the research participants consisted of 59 students, 31 of which are male and 28 of which are female.

\section{Data collection tools}

Two data collection tools were used in this study. The first tool is a demographic questionnaire containing students gender, age and mathematics class notes. As the second data collection tool, "Multiple Representations in Fraction Operations Test" was used (Appendix 1). In order to construct the test, firstly the curriculum objectives related to the concepts were examined. In accordance with the number of objectives and the course hours devoted to the addition and subtraction of fractions, a trial test was prepared with 30 test items consisting of 8 main questions and sub-questions. In order to determine the validity and reliability of the test, three expert opinions were taken from the mathematics education field. Coverage validity of the instrument achieved through the step that the experts indicate whether each test item is eligible by marking the "suitable," "not suitable" and "needs to be changed" options according to their intelligibility, quality and level criteria.

In order to determine the validity and reliability of the 30-question trial test, the pre-test was conducted on 59 students in two middle schools in Kastamonu (Turkey) province center. According to the results of the application, item difficulty index and item discrimination index were calculated for each question (Table 1). According to the item difficulty and discrimination analysis, it was found that the items with the item discrimination index between -1 and 0 were removed from the test, 
the items between 0 and 0.30 were corrected and the items higher than 0.30 were used directly in the test.

Table 1. Results of multiple representations in fraction operations test item analysis

\begin{tabular}{cccccc}
\hline $\begin{array}{c}\text { Item } \\
\#\end{array}$ & Difficulty & $\begin{array}{c}\text { Distinctive- } \\
\text { ness }\end{array}$ & $\begin{array}{c}\text { Item } \\
\#\end{array}$ & Difficulty & $\begin{array}{c}\text { Distinctive- } \\
\text { ness }\end{array}$ \\
\hline 1 & 0.75 & 0.49 & 16 & 0.51 & 0.75 \\
\hline 2 & 0.81 & 0.49 & 17 & 0.58 & 0.72 \\
\hline 3 & 0.25 & 0.78 & 18 & 0.29 & 0.76 \\
\hline 4 & 0.32 & 0.54 & 19 & 0.22 & 0.69 \\
\hline 5 & 0.69 & 0.49 & 20 & 0.66 & 0.64 \\
\hline 6 & 0.31 & 0.83 & 21 & 0.37 & 0.85 \\
\hline 7 & 0.63 & 0.62 & 22 & 0.56 & 0.65 \\
\hline 8 & 0.34 & 0.56 & 23 & 0.24 & 0.74 \\
\hline 9 & 0.25 & 0.63 & 24 & 0.27 & 0.70 \\
\hline 10 & 0.64 & 0.70 & 25 & 0.49 & 0.82 \\
\hline 11 & 0.61 & 0.69 & 26 & 0.47 & 0.81 \\
\hline 12 & 0.27 & 0.75 & 27 & 0.22 & 0.74 \\
\hline 13 & 0.36 & 0.81 & 28 & 0.27 & 0.74 \\
\hline 14 & 0.73 & 0.47 & 29 & 0.44 & 0.85 \\
\hline 15 & 0.76 & 0.53 & 30 & 0.39 & 0.78 \\
\hline
\end{tabular}

The KR-20 reliability coefficient of this test was calculated as 0.96. As a result, "Multiple Representations in Fraction Operations Test " prepared in line with item analysis and expert opinions was used as data collection tool. The final state of the test consists of 8 main questions and a total of 30 open ended questions including three inter-representative transitions under these questions. The distribution of the questions in the test is given in Table 2.

\section{Coding procedures}

At the beginning of the study, in order to create the coding list, the related literature was examined, the representation types determined in the addition-subtraction operations in fractions were developed and the representations to be used in the codes were decided. In Table 3, the criteria used to assess the skills of the students on the representation determined in the study are given. Two experts working independently were involved in the coding process of the data. Both experts have numerous studies regarding use of multiple representations in mathematics education. As a result of the first coding, the agreement rate (reliability coefficient) between coders was calculated as $88.7 \%$ according to the Miles and Huberman (1994) formula. The coders came together and discussed the items causing the dispute and reached an agreement on each item.

Table 3. Criteria for creating representations

\begin{tabular}{|c|c|c|c|}
\hline $\begin{array}{l}\text { 1) Writing the mathematical } \\
\text { expression of the rep- } \\
\text { resentation } \\
\text { 2) Denominator equalization } \\
\text { if necessary } \\
\text { 3) Expressing the given oper- } \\
\text { ation numerically } \\
\text { 4) Performing the operation }\end{array}$ & $\begin{array}{l}\text { 1) Drawing the number line } \\
\text { 2) Placing the integers } \\
\text { 3) Separating by equal units } \\
\text { (determining the denominator) } \\
\text { 4) Expressing fractions (show- } \\
\text { ing numerator with arrows) } \\
\text { 5) Performing the given } \\
\text { operation } \\
\text { 6) Showing the result (arrowing } \\
\text { out) }\end{array}$ & $\begin{array}{l}\text { 1) Expressing the given fractions } \\
\text { (verbal) correctly } \\
\text { 2) Identification of objects suit- } \\
\text { able for given fractions (wholes } \\
\text { to be fragmented) } \\
\text { 3) Performing the given opera- } \\
\text { tion in the text } \\
\text { 4) To be able to express the } \\
\text { process given at the root of the } \\
\text { question. }\end{array}$ & $\begin{array}{l}\text { 1) Drawing a closed figure } \\
\text { divided by the appropriate units } \\
\text { for given fractions (Determining } \\
\text { the denominator) } \\
\text { 2) Screening the requested part } \\
\text { according to the given fractions } \\
\text { (determining the numerator) } \\
\text { 3) Denominator equalization if } \\
\text { necessary } \\
\text { 4) Performing the given action } \\
\text { on figures }\end{array}$ \\
\hline
\end{tabular}

Table 2. Multiple Representations in Fraction Operations Test question distributions

\begin{tabular}{|c|c|c|c|}
\hline \multirow{2}{*}{$\begin{array}{l}\text { The type of } \\
\text { representation } \\
\text { the problem is } \\
\text { given }\end{array}$} & \multicolumn{2}{|c|}{ Question number } & \multirow{2}{*}{$\begin{array}{l}\text { Type of } \\
\text { representation } \\
\text { required to } \\
\text { transit }\end{array}$} \\
\hline & Addition & Subtraction & \\
\hline \multirow{4}{*}{ Model } & 1 & 5 & Model \\
\hline & $1 a$ & $5 a$ & Numerical \\
\hline & $1 b$ & $5 b$ & Number line \\
\hline & $1 c$ & $5 c$ & Verbal \\
\hline \multirow{4}{*}{ Numerical } & 2 & 6 & Numerical \\
\hline & $2 a$ & $6 a$ & Number line \\
\hline & $2 b$ & $6 b$ & Model \\
\hline & $2 c$ & $6 c$ & Verbal \\
\hline \multirow{4}{*}{ Number line } & 3 & 7 & Number line \\
\hline & $3 a$ & $7 a$ & Numerical \\
\hline & $3 b$ & $7 b$ & Model \\
\hline & $3 c$ & 7c & Verbal \\
\hline \multirow{3}{*}{ Verbal } & $4 a$ & $8 a$ & Number line \\
\hline & $4 b$ & $8 b$ & Model \\
\hline & $4 c$ & $8 c$ & Numerical \\
\hline
\end{tabular}

\section{Data analysis}

The achievement rate of the students related to transiting among the representations have calculated through correct answers given to the related questions. In this calculation, it is taken into account the expressions of the questions (in writing) and the representations which are used in the solution of the questions. By creating these two different categories, it is aimed to determine the direction of the transition. For example, if a question is given in a numerical form, and verbal explanations are sought in the solution, then a judgment has been reached that there is a transition from numerical representation to verbal representation in this question. Students' skills of creating each representation was analyzed by means of the criteria

\section{Findings}

Findings regarding the transition skills of sixth grade students in the addition and subtraction of fractions are given in Table 4. When the table is examined for addition operation, it has been determined that the students are more successful in situations where the numerical response to the question given in the form of model representation (transition from model to numerical mode) and the cases where the numerical expression of the verbal questions is requested (verbal to numerical transition). Again, it turns out that the majority of students are successful in tranmentioned in Table 3. 
sitions requiring to construct model and numerical representations in the addition operation. On the other hand, students' performance in the transition where the number line representation and the verbal representation are required have been relatively low (between 14\% and 22\%).

Table 4. Students' achievement rate in transiting between representations (\%)

\begin{tabular}{lcccccccccc}
\hline & To: & Model & \multicolumn{2}{c}{ Numerical } & \multicolumn{2}{c}{$\begin{array}{c}\text { Number } \\
\text { line }\end{array}$} & \multicolumn{2}{c}{ Verbal } \\
\hline From & + & - & + & - & + & - & + & - \\
\hline Model & 64 & 39 & 76 & 47 & 10 & 34 & 19 & 7 \\
\hline Numerical & 54 & 47 & 64 & 59 & 15 & 24 & 20 & 8 \\
\hline Number line & 51 & 34 & 54 & 36 & 10 & 15 & 14 & 7 \\
\hline Verbal & 66 & 31 & 75 & 29 & 22 & 14 & NR & NR \\
\hline Note: NR: Transition not required & & & & & &
\end{tabular}

When the findings of subtraction operation are examined from table 4 , it is seen that the achievement status of the students in general is lower than their achievement rates in the addition operation. Moreover, it was determined that the situation in which the students were most successful in transition between representations was determined as the transition which a numerical answer was required for the numerical question (59\%). Again, it turns out that almost half of the students are successful in the questions requiring model-numerical and numerical-model transition in the subtraction operation. On the other hand, it is observed that in the case of the remaining representation transition pairs in the subtraction operation, the students show very low achievement, especially in transitions requiring verbal representation creation.

\section{Issues encountered in forming representations}

In this section, problems encountered about the representations are analyzed and presented according to previously determined criteria. The values given were obtained from the responses given to the questions to form each representation.

\section{Issues in model representation forming}

Table 5 lists the difficulties that students encounter in model representation during addition and subtraction in fractions. When the table is examined, students' difficulties were encountered in all the steps that should be followed during the model representation forming process. While adding fractions on a model, students have made more mistakes in the steps determining the denominator and fulfilling the operations. It has been observed that students left more unanswered questions in the subtraction operation. Moreover, it is seen that the mistakes that students make during the steps of fulfilling the operations and determining the numerator are also more prevalent in the subtraction operation.

Figure 1 provides an example of a mistake in the denominator determination stage in addition operation. According to the figure, the student was asked to add up the fractions $2 / 12$ and 4/12 given on the model. The student has drawn a figure of 8 units (denominator) and marked 6 units (numerator) in the model created in the answer and expressed the solution as 6/8. When performing the addition operation on the model representation, student is seen to not focus on denominator on the final answer but only added up the hatched areas.
Table 5. Issues encountered in model representation forming (f)

\begin{tabular}{cccc}
\hline Steps & Addition & Subtraction & Total \\
\hline $\begin{array}{c}\text { Determining } \\
\text { the denomi- } \\
\text { nator }\end{array}$ & 55 & 48 & 103 \\
\hline $\begin{array}{c}\text { Determining } \\
\text { the numer- } \\
\text { ator }\end{array}$ & 43 & 55 & 98 \\
\hline $\begin{array}{c}\text { Equalizing de- } \\
\text { nominators if } \\
\text { necessary }\end{array}$ & 30 & 52 & 82 \\
\hline $\begin{array}{c}\text { Fulfilling the } \\
\text { operation }\end{array}$ & 48 & 72 & 120 \\
\hline Unanswered & 18 & 47 & 65 \\
\hline
\end{tabular}

1) Model ile verilmiş olan işlemi yapınız. (Perform the operation given on the model.)

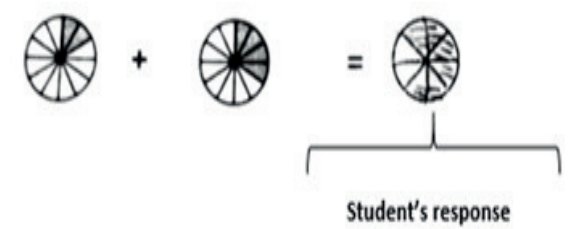

Figure 1. Denominator mistake in transition from model representation to model representation (S28)

An example of a mistake in performing operation is shown in figure 2. Here, the student identified fractions given verbally (three tenths and two tenths) on the model separately, but on the model formed in the answer while performing the addition operation, drew a 10-unit figure (denominator) and marked 4 unit (numerator) and expressed the answer as 4/10. While the student was performing the addition operation in the form of a model representation, he could divide the whole into equal parts but could not mark the required part (numerator).

\section{4) "Ezgi reed three tenths of her story book first, and then two tenths." So, how many of the book did Ezgi} read?"

b) Bu işlemi model kullanarak ifade ediniz. (Perform this operation using model representation.)

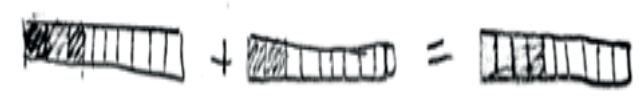

Figure 2. Mistake in performing operation transition from a verbal representation to model representation (S16)

Figure 3 shows an example of a mistake in denominator equalization and performing an operation in transition from model representation to model representation. When the fractions given in the model representation are examined, it is observed that the student cannot divide the second whole in the same way as the first whole in terms of procedural skill (to achieve equal denominators), and could not divide into suitable unit in the new fraction formed when subtracted the unequal denominators from each other.

\section{Issues encountered in numerical representation forming}

In Table 6, the problems that students encounter while forming numerical representation are presented in accordance with predetermined criteria. It is seen from that mistakes were encountered in each of the steps to be followed in the process of creating a numerical representation while the frequencies of the mistakes encountered in conducting numeric operations were less than those in model operations of fractions. However, there was more 
unanswered questions in numerical representations ( $f=$ 84) than model ones $(f=65)$.

5) Model ile verilmiş olan işlemi yapınız. (Perform the operation given on the model.)

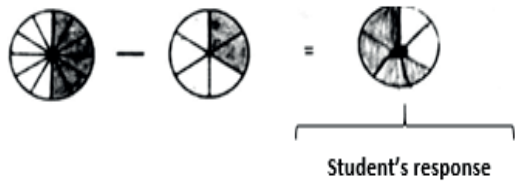

Figure 3. Mistake in denominator equalization and performing an operation in transition from model representation to model representation (S72)

While adding fractions by using numerical representations, students suffered from more mistakes in the steps of performing the operation and writing the numerical expression of the representation. It has been observed that students left the questions in the subtraction operation unanswered more, mistakes were encountered more in the performing operation stage in subtraction operation.

Table 6. Issues encountered in numerical representation forming (f)

\begin{tabular}{cccc}
\hline Steps & Addition & Subtraction & Total \\
\hline $\begin{array}{c}\text { Writing the numerical } \\
\text { expression of the } \\
\text { representation }\end{array}$ & 27 & 30 & 57 \\
\hline $\begin{array}{c}\text { Expressing the operation } \\
\text { numerically }\end{array}$ & 17 & 30 & 47 \\
\hline $\begin{array}{c}\text { Equalizing denominators } \\
\text { if necessary }\end{array}$ & 19 & 34 & 53 \\
\hline Performing the operation & 39 & 56 & 95 \\
\hline Unanswered & 27 & 57 & 84 \\
\hline
\end{tabular}

When the mistakes frequently encountered by the students in the numerical representation are examined, it is seen in figure 4 that the student who correctly express the fractions given in model representation cannot numerically subtract the fractions. It is understood from the operation performed, (s)he subtracted first numerator from the second to find to the numerator, and subtracted denominator from denominator to calculate the denominator. He performed the subtraction operation by thinking denominator and numerator separately. In other words, it is seen that the result is obtained by subtracting numerators and denominators by themselves.

5) Perform the operation given below and answer the questions a, b, c accordingly.

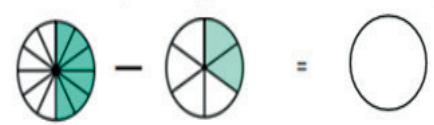

a) Bu işlemi sayısal olarak ifade ediniz. (Perform this operation using numerals.)

$$
\frac{6}{12}-\frac{2}{6}=\frac{4}{6}
$$

Figure 4. Performing operation mistake in transition to model representation to numerical representation (S68)

In Figure 5, an exemplary case of denominator equalization mistake is shown. In this question, it is required to numerically subtract fractions given in numerical representation. When the student performs the operation it appears that he knows that denominator equalization is necessary but he performs the operation without extending the numerator with regards to obtaining an equal fraction by extending the fraction to equalize the denominator.
6) Aşă̌ıda verilmiş olan işlemi yapınız ve a, b, c, şıllarındaki soruları bu soruya göre cevaplandirniz. (Perform the operation given below and answer the questions $a, b, c$ accordingly.)

$$
\frac{5}{6}-\frac{1}{3}=\frac{5}{6}-\frac{1}{6}=\frac{4}{6}
$$

Figure 5. Denominator equalization mistake in forming a numerical representation (S12)

Issues encountered in number line representation forming

Table 7 presents the mistakes the students made when performing the addition and subtraction of fractions on the number line. It has been determined that students make numerous mistakes in the steps of expressing fractions on the number line (showing by arrows), determining the given operation on the number line and showing the result (by arrowing out), although the mistakes are encountered at each step in general. On the other hand, it has been observed that most students left these questions unanswered.

Table 7. Issues encountered in number line modeling forming (f)

\begin{tabular}{cccc}
\hline Steps & Addition & Subtraction & Total \\
\hline $\begin{array}{c}\text { Drawing the number } \\
\text { line }\end{array}$ & 1 & 1 & 2 \\
\hline Placing the integers & 22 & 14 & 36 \\
\hline $\begin{array}{c}\text { Separating by equal } \\
\text { units (determining the } \\
\text { denominator) }\end{array}$ & 55 & 45 & 100 \\
\hline $\begin{array}{c}\text { Expressing fractions } \\
\text { (showing numerator } \\
\text { with arrows) }\end{array}$ & 105 & 75 & 180 \\
\hline $\begin{array}{c}\text { Determining the oper- } \\
\text { ation }\end{array}$ & 88 & 88 & 176 \\
\hline $\begin{array}{c}\text { Showing the result } \\
\text { (arrowing out) }\end{array}$ & 123 & 90 & 213 \\
\hline Unanswered & 55 & 81 & 136 \\
\hline
\end{tabular}

1) Perform the operation given below and answer the questions a, b, c accordingly.

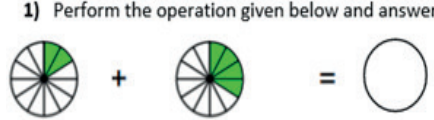

b) Bu işlemi sayı doğrusu üzerinde gösteriniz. (Perform this operation on the number line.)

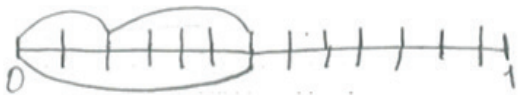

Figure 6. Separating into equal units (determining the denominator) (S64)

Figure 6 provides an example of one of the mistakes that students often make which is to divide the whole into equal parts and identify on the number line, i.e. placing the denominators. While the whole is required to be divided into twelve equal parts on the number line, it is seen that twelve lines were drawn on the whole and divided into thirteen parts.

In figure 7, there is an example of a mistake for performing the operation. The student was able to construct the number line correctly while performing the operation on the number line. However, when performing the addition operation on the number line, focused only on the fractional expressions, and identified the places of these on the number line and showed the numerically known (calculated) value on the number line. Student could not perform addition operation in fractions by using number line. 
4) "Ezgi read three tenths of her story book first, and then two tenths." So, how many of the book did Ezgi read?" Express the problem given in this text verbally and solve it, and answer the questions in a, b, c accordingly.

a) Bu işlemi sayı doğrusu üzerinde gerçekleştiriniz. (Perform this operation on the number line.)

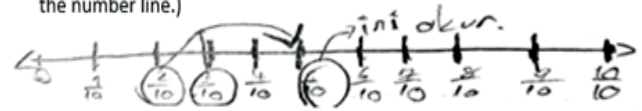

Figure 7. Example of performing an operation mistake (S27)

\section{Issues encountered in verbal representations}

In table 8, the mistakes the students made when performing the addition and subtraction operations on the verbal representation in fractions were identified. In general, mistakes were encountered in each step, but it has been determined that most of the mistakes are made by the students in the steps of creating the verbally appropriate scenarios and expressing the operation given at the root of the question correctly. It is noteworthy that the number of unanswered questions in the addition subtraction operation in verbal representations is rather high, and that the number of unanswered questions is higher in subtraction operation compared to addition.

Table 8. Issues encountered in verbal representation forming (f)

\begin{tabular}{cccc}
\hline Steps & Addition & Subtraction & Total \\
\hline $\begin{array}{c}\text { Expressing the fractions } \\
\text { correctly }\end{array}$ & 32 & 24 & 56 \\
\hline $\begin{array}{c}\text { Identification of objects } \\
\text { suitable for given } \\
\text { fractions (wholes to be } \\
\quad \text { fragmented) }\end{array}$ & 25 & 33 & 58 \\
\hline $\begin{array}{c}\text { Creating a scenario that } \\
\text { is suitable for given } \\
\text { operation }\end{array}$ & 36 & 60 & 96 \\
\hline $\begin{array}{c}\text { Being able to express } \\
\text { the operation given at } \\
\text { the root of the question. }\end{array}$ & 84 & 82 & 166 \\
\hline$\quad$ Unanswered & 52 & 69 & 121 \\
\hline
\end{tabular}

c) Bu ișlem ile ilgili bir problem kurunuz. (Pose a problem related to this operation.)

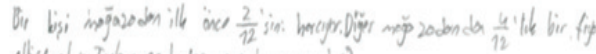

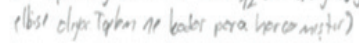

(A person spends $2 / 12^{\prime}$ th of his/her money in a shopping center. Then (s) he spends $4 / 12^{\prime}$ th of the money for a dress in another shop. How much money did (s)he spend?)

Figure 8. Mistake in scenario creation and question root determination in transition to model representation to verbal representation (S27)

In figure 8, an example of mistakes in creating scenarios and expressing the operation given in the root of the question in relation to the verbal representation of the model representation addition operation is given. The student has set up a scenario by expressing mathematically the fractions given and spent 2/12 of his money first, then $4 / 12$ of it in the scenario. The student, while creating the problem scenario, could not reveal the initial situation clearly, could not express the sentences fully and also formed a question root as "how much money did (s) he spent" while it should've been "what was the portion of the money that (s)he spent?"

In figure 9, an example of a mistake in creating a scenario that is suitable for given operation (subtraction in this case) is given. The student has correctly expressed fractions in the given (as model) subtraction operation. Although (s)he expressed the subtraction operation by asking the remaining amount, (s)he set up a scenario requiring the addition of fractions. In addition to this, the question root asked about the number of slices, not the fractional result, resulting in a situation that the answer should be a natural number.

c) Bu işlem ile ilgili bir problem kurunuz. (Pose a problem related to this

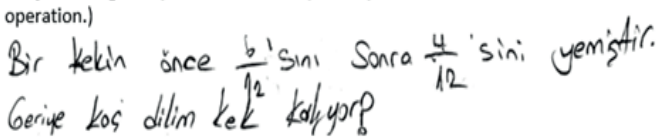

(I have first eaten $6 / 12^{\prime}$ th of the cake and then $4 / 12^{\prime}$ th of it. How many slices of cake do I have left?)

Figure 9. Mistake in creating a scenario suitable for the operation (S15)

In figure 10, an example of mistake in identifying an object suitable for operation (fragmentable) is given. This question requires constructing a verbal representation appropriate to the subtraction operation given on the number line. The student has not been able to express exactly the fragmentable wholes even though (s)he identified the fractions correctly. It has been seen that the student has set up a problem sentence requiring a subtraction operation as question root but he has expressed the subtraction operation with natural numbers (20 pieces) instead of the subtraction operation with fractions.

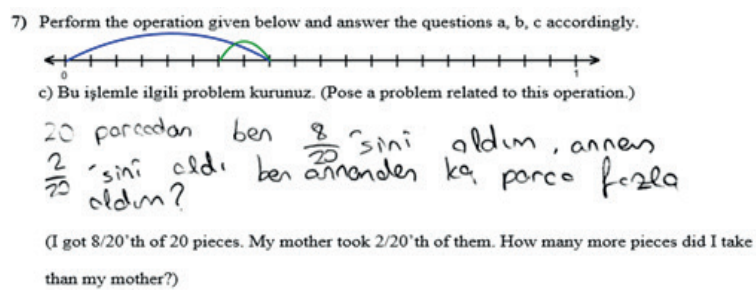

Figure 10. Mistake in identifying suitable objects for given fractions (wholes to be fragmented) and being able to express the operation given in question root (S32)

\section{Conclusions and Discussion}

In this study, using multiple representations and transformations into each other were sought by focusing on model, number line, verbal and numerical representations involved in addition and subtraction operations in fractions. According to research findings, it has been determined that the achievement of students in using different representations in operations with fractions is higher in addition operation compared to subtraction operation. In addition, it turns out that students are more successful in numerical-numerical, model-model, model-numerical, and numerical-model transitions compared to other transitions in both operation types. This situation is in parallel with the different studies that reveal student achievement towards numerical and model representations (Herman, 2002, Pitts, 2003, Şiap \& Duru, 2004). It was also found out that they fail in other representation types such as number line and verbal representation transition situations. Students also expressed the difficulties experienced by students in verbal (Sert, 2007) and numerical line representations (Kılıç \& Özdaş, 2010).

In forming model representation, more mistakes were identified in the denominator and numerator determination steps in addition operation. On the other hand, mistakes in subtraction of fractions were more frequent in the steps of performing the operations and determining the numerator. This situation indicates the difficulties that students have experienced in constructing the concept of fraction. The use of models in the teaching of fractions 
and in the construction of fractional numbers is the basis for the development of fractional numbers (Vergnaud, 1983). The use of a number of models and manipulative tools in introduction to fractions makes it easier to learn the concept of fractions and makes it easier for students to deal with fractions because it makes the fractions concrete for elementary school primary learners who are still in the concrete operations stage (Kieren, 1976).

In numerical representations, students were more challenged in the subtraction operation, and mistakes were made in the steps of performing the operation and writing the numerical expression of the representation. Particularly, in the fractions with different denominators, it is determined that the students continue their natural habits and that they consider the denominators and numerators as separate numbers and add. The relevant problem has been widely described in the literature (Carpenter, Coburn, Reys, \& Wilson, 1976; Işık \& Kar, 2012).

In representation of number line, the difficulty experienced by the students in dividing number line into required denominator was the result of dividing into missing or more equal parts. Similar difficulties that students have experienced with respect to the number line have also been demonstrated by Pesen (2008). The situations in which the students create verbal representation types in the addition and subtraction operations of fractions are examined and different errors are noticed in the operation steps according to the results. In this case, where the students preferred non-fragmentable wholes, the situation emerged as perceiving the question as rational number rather than fraction meaning.

It was determined that, while performing addition and subtraction operation in fractions on the verbal representation, the students generally made mistakes at each step, but most mistakes were made in the forming suitable scenario and being able to express the operation given at the question root correctly stages. It has been found that the students made mistakes in the addition and subtraction operations in forming the root of the question. Moreover, setting up sentences that give the meaning of integer to a fraction was among the most frequent question root mistakes. Işık and Kar (2012), in the study they conducted, have also identified problems such as the inability of the students to perceive the quantities specified by the numbers in the fraction operations and the inability to reflect the operation to the root of the question. The content of the identified difficulties and the high number of difficulties identified in the established problems indicate that the students are lacking conceptual dimension for fractions and addition and subtraction operation in fractions. This result supports the conclusion that the difficulties oriented to fraction operations cannot be evaluated separately of difficulties in learning fractions and the roots are based on fraction concepts as indicated by Charalambous, Delaney, Mhuire, Hsu and Mesa (2010). Students' difficulties in adding and subtracting fractions have concerned educators for years. Researchers have also explored what causes student errors such as adding (or subtracting) the numerators and the denominators. This exploration suggested that several cognitive factors might explain such errors. For instance, it was proposed that students often view fractions as two separate whole numbers (one corresponding to the numerator and another to the denominator) rather than as individual quantities (Carpenter et al., 1976), and that they are often misguided by inappropriate analogies (e.g., they believe that when adding or subtracting fractions it is legitimate to add or subtract the numerators and denominators because in the multiplication of fractions one multiplies the numera- tors and the denominators) (Vinner, Hershkowitz, \& Bruckheimer, 1981).

Students' difficulties in adding and subtracting fractions cannot be separated from their difficulties in learning fractions generally. Studies suggest that such difficulties have their roots in the complexity of the notion of fractions and in instructional approaches employed when teaching fractions (Ball, 1993; Behr, Harel, Post, \& Lesh, 1993; Lamon, 1999). For example, meanings, models, and symbols that worked well for students when working on whole numbers may interfere with students' developing understanding of fractions (Lamon, 1999). Furthermore, fractions make up a multifaceted concept, consisting of five interrelated constructs: part-whole, measure, operator, quotient, and ratio (Kieren, 1976). Because each construct captures different aspects of fractions, constructing a comprehensive schema of fractions requires developing a robust understanding of all five constructs and of their confluence (Behr et al., 1993).

Research has also shown that instruction may impede the learning of fractions, especially when (1) it fails to build on students' prior knowledge (Mack, 2001), (2) it emphasizes rote learning at the expense of conceptual understanding (Ball, 1993; Mack, 2001), (3) it introduces formal symbols and algorithms before familiarizing students with the different aspects of the notion of fractions (Smith, 2002), or (4) it emphasizes only one of the constructs (usually the part-whole construct, (Moss \& Case, 1999). Textbooks, as one tool of instruction, may contribute to compounding or ameliorating such difficulties. In the framework used in the present study such criteria are given detailed consideration.

Findings obtained from this study are thought to be important for those who guide educational policies and those who contribute to the preparation of the mathematics curriculum. Educational research studies are important for shedding light on the development of educational reforms and the curricula prepared in this direction. In this context, it is thought that the institutions or individuals involved in this process will contribute to matching the findings obtained from this study with targeted outputs in educational policies or curricula.

This is a study conducted in the form of special case analysis. Further qualitative or interventional research that focuses on teachers' classroom practices, student preferences for representation and ability to use representations might be useful to investigate and broaden the results obtained in this study. It is also contemplated that tools developed to determine the representation usage competencies or skills, perceptions or attitudes towards representations of students (or teachers) will contribute to quantitative and qualitative studies with subject of "multiple representations and mathematics learning".

The results of the research indicate that students are experiencing difficulties in verbal representations of addition and subtraction operations in fractions. In order to develop the skills of problem-solving in the development of these skills, it is important to establish a relationship between real life situations and fractions (Abu-Elwan, 2002, Akay \& Boz, 2008, Dickerson, 1999, Işık, Işık, \& Kar, 2011). Moreover, these activities support the conceptual understanding in the students (Akay, 2006; Crespo and Sinclair, 2008; English, 1998, 2003; Işık, 2011; Stickles, 2006; TolukUçar, 2009). For these reasons, teachers should provide students with the opportunity to express themselves in a verbal and linguistic way in order to improve their problem-solving skills in lessons and give students opportunities to problem-solve as well as problem-solving methods. 
Again, while the verbal questions are being asked, the scenario part should be cut in half and the students should be asked to complete or the part of the question root should be left empty, students should be gained expressing fractions.

Fractions are conceptually abstract for middle school students. When the concept of fractions is explained only by verbal expressions or numerical representations, students cannot understand these concepts that are abstract to them (Piaget, 1952). For this reason, the use of models and teaching materials that represent multiple forms of representation in the teaching of addition and subtraction in fractions is crucial for the realization of meaningful learning. This study can be regarded as a study that especially sheds light on teacher and teacher candidates.

\section{References}

Abu-Elwan, R. (1999). The development of mathematical problem posing skills for prospective middle school teachers. In A. Rogerson (Ed.) Proceedings of the international conference on mathematical education into the 21st century: Social Challenges, Issues and Approaches, (Vol. II, pp. 1-8), Cairo Egypt.

Ainsworth, S. (1999). The functions of multiple representations. Computers and Education, 33,131-152.

Ainsworth, S. (2006). DeFT: A conceptual framework for considering learning with multiple representations. Learning and Instruction, 16(3), 183-198.

Ainsworth, S. (2008). The educational value of multiple-representations when learning complex scientific concepts. In Gilbert, J.K., Reiner, M. ve Nakhleh, M. (Eds), Visulaziation: Theory and Practice in Science Education(pp.191-208). Springer.

Ainsworth, S. E., Bibby, P.A., \& Wood, D. J. (1997). Information technology and multiple representations: New opportunities-new problems. Journal of Information Technology for Teacher Education, 6(1), 93105

Akay, H. (2006). Problem kurma yaklaşımı ile yapılan matematik öğretiminin öğrencilerin akademik başarısı, problem çözme becerisi ve yaratıcılı̆̆ı üzerindeki etkisinin incelenmesi (Yayınlanmamış Doktora Tezi). Gazi Üniversitesi, Ankara.

Akay, H., \& Boz, N. (2008). Prospective teachers' views about problem-posing activities. Procedia Social and Behavioral Sciences, 1, 1192-1198.

Akkuş-Çıkla, O. (2004). The effects of multiple representations-based instruction on seventh grade students algebra performance, attitude toward mathematics, and representation preference. Yayımlanmamış Doktora Tezi. Middle East Technical University, Ankara.

Alacacı, C. (2010). Öğrencilerin kesirler konusundaki kavram yanılgıları. E. Bingölbali ve M.F. Özmantar (Ed.), Matematiksel Zorluklar ve Çözüm Önerileri. Ankara: PegemA Yayıncılık.

Ball, D. L. (1993). Halves, pieces, and twoths: Constructing and using representational contexts in teaching fractions. Rational numbers: An integration of research, 157-195.
Baştürk, S. (2010). Öğrencilerinin fonksiyon kavramının farklı temsillerindeki matematik dersi performansları. Gazi Eğitim Fakültesi Dergisi, 30(2), 465482.

Behr, M., Harel, G., Post, T. \& Lesh, R. 1993. Rational numbers: Toward a semantic analysis. In Carpenter, T. P., Fennema, E. and Romberg, T. A (Eds), Rational numbers: An integration of research, (pp. 13-47). Hillsdale, NJ: Lawrence Erlbaum.

Behr, M., Harel, G., Post, T., \& Lesh, R. (1994). Units of quantity: A conceptual basis common to additive and multiplicative structures. In G. Harel \& J. Confrey (Ed.), The development of multiplicative reasoning in the learning of mathematics (pp. 123-180). Albany, NY: SUNY Press.

Biber Ç., Tuna A., \& Aktaş O. (2013). Öğrencilerin kesirler konusundaki kavram yanılgıları ve bu yanılgıların kesir problemleri çözmüne etkisi. Trakya University Journal of Education, 3(2), 152-162.

Bruner, J. S. (1960). On learning mathematics. The Mathematics Teacher, 4, 129-136.

Carpenter, T. P., Coburn, T. G., Reys, R. E., \& Wilson, J. W. (1976). Notes from national assessment: Addition and multiplication with fractions. Arithmetic Teacher, 23, 137-141.

Cobb, P., Yackel, E., \& Wood, T. (1992). A constructivist alternative to the representational view of mind in mathematics education. Journal for Research in Mathematics Education, 23(1), 2-33.

Charalambous, C. Y., Delaney, S., Hsu, H. Y., \& Mesa, V. (2010). A comparative analysis of the addition and subtraction of fractions in textbooks from three countries. Mathematical Thinking and Learning, 12, 117-151.

Corter, J., \& Zahrer, D. (2007). Use of external visual representations in probability problem solving. Statistics Education Research Journal, 6(1), 22-50.

Cramer, K. (2003). Using a translation model for curriculum development and classroom instruction. In R. Lesh \& H. M. Doerr (Ed.), Beyond constructivism: Models and modeling perspectives on mathematics teaching, learning, and problem solving (pp. 449-463). Mahwah, NJ: Lawrence Erlbaum Associates, Inc.

Crespo, S., \& Sinclair, N. (2008). What makes a problem mathematically interesting? Inviting prospective teachers to pose better problems. Journal Mathematics Teacher Education, 11, 395-415.

Çepni, S. (2012). Araştırma ve proje çalışmalarına giriş. Trabzon: Celepler Matbaacılık.

Dickerson, V. M. (1999). The impact of problem-posing instruction on the mathematical problem-solving achievement of seventh graders (Unpublished doctoral dissertation). University of Emory, Atlanta.

Dienes, Z. P. (1960). Building up mathematics. Great Britain: Anchor Press, Hutchinson Educational.

Dufour-Janvier, B., Bednarz, N., \& Belanger, M. (1987). Pedagogical considerations concerning the problem of representation. In C. Janvier (Ed.), Problems 
of Representations in the Learning and Teaching of Mathematics,(pp. 109-123). New Jersey: Yayınevi.

Duval, R. (2006). A cognitive analysis of problems of comprehension in a learning of mathematics. Educational Studies in Mathematics, 61(1), 103-131.

Edwards, L. D. (1998). Embodying mathematics and science: Microworld as representations. The Journal of Mathematical Behavior, 17(1), 53-78.

English, L. D. (1998). Children's problem posing within formal and informal contexts. Journal for Research in Mathematics Education, 29(1), 83-106.

English, L. D. (2003). Problem posing in elementary curriculum. In F. Lesterve R. Charles (Eds.), Teaching mathematics through problem solving. Reston, Virginia: National Council of Teachers of Mathematics.

Gagatsis, A., \& Shiakalli, M. (2004). Ability to translate from one representation of the concept of function to another and mathematical problem solving. Educational Psychology, 24(5), 645-657.

Goldin, G. A., \& Janvier, C. (1998). Representations and the psychology of mathematics education. Journal of Mathematical Behavior, 17(1), 1-4.

Herman, M. F. (2002). Relationship of college students'visual preference to use of representations: Conceptual understanding of functions in algebra (Unpublished PhD dissertation). Columbus: Ohio State University.

Işık, C. (2011). Illköğretim Matematik Öğretmeni AdayIarının Kesirlerde Çarpma ve Bölmeye Yönelik Kurdukları Problemlerin Kavramsal Analizi. Hacettepe Üniversitesi Eğitim Fakültesi Dergisi, 41, 231-243.

Işık, C., Işık, A., \& Kar, T. (2011). Öğretmen adaylarının metinsel ve görsel temsillere yönelik kurdukları problemlerin analizi. Pamukkale Üniversitesi Eğitim Fakültesi Dergisi, 39-49.

İpek, A. S., \& Okumuş, S. (2012). İlköğretim matematik öğretmen adaylarinin matematiksel problem çözmede kullandiklari temsiller. Gaziantep Üniversitesi Sosyal Bilimler Dergisi, 11(3), 681-700.

Kaput, J. J. (1989). Linking representations in the symbol systems of algebra. In S. Wagner ve C. Kieran (Eds). Research issues in the learning and teaching of algebra (pp. 167-194). Hillsdale, NJ: LEA.

Kaput, J. J., Blanton, M. L., \& Moreno, L. (2008). Algebra from a symbolization point of view. In J. J. Kaput, D. W. Carraher, \& M. L. Blanton (Ed.), Algebra in the early grades (pp. 19-55). New York: LEA \& NCTM.

Kılıç, Ç., \& Özdaş, A. (2010). İlköğretim 5. sınıf öğrencilerinin kesirlerde karşılaştırma ve sıralama yapmayı gerektiren problemlerin çözümlerinde kullandıkları temsiller. Kastamonu Ĕgitim Dergisi, 18(2), 513-530.

Kieren, T. E. 1976. On the mathematical, cognitive, and instructional foundations of rational numbers. In $\mathrm{R}$. Lesh (Ed.), Number and measurement: Papers from a research workshop, (pp. 101-144). Columbus, $\mathrm{OH}$ : ERIC/SMEAC
Lamon, S. J. 1999. Teaching fractions and ratios for understanding. Mahwah, NJ: Erlbaum.

Lesh, R. (1999). The development of representational abilities in middle school mathematics. In I. E. Sigel (Ed.), Development of mental representation: Theories and application (pp. 323-350). Mahwah, NJ: Lawrence Erlbaum.

Lesh, R., Landau, M., \& Hamilton, E. (1983). Conceptual models in applied mathematical problem solving. In R. Leshve M. Landau (Eds.), Acquisitionof Mathematics Concepts and Processes,(pp. 263-343). New York: Academic Press.

Mack, N. K. 2001. Building on informal knowledge through instruction in a complex content domain: Partitioning, units, and understanding multiplication of fractions. Journal for Research in Mathematics Education, 32, 267-295.

Mick, H. W., \& Snicrope, R. (1989). Two meanings of fraction multiplication. School Science and Mathematics, 89(8), 632-639.

Miles, M. B., Huberman, A. M., \& Saldana, J. (1984). Qualitative data analysis: A sourcebook. Beverly Hills.

Ministry of National Education (MoNE) (2013). Ortaokul matematik dersi $(5,6,7$ ve 8 . Sinıflar) matematik dersi öğretim programı. Ankara.

Moss, J., \& Case, R. 1999. Developing children's understanding of the rational numbers: A new model and an experimental curriculum. Journal for Research in Mathematics Education, 30, 122-147.

Moseley, B., \& Brenner, M. E. (1997). Using multiple representations for conceptual change in pre-algebra: $A$ comparision of variable usage with graphic and text based problems. (ERIC Document Reproduction Service: ED413184).

Nair, A. \& Pool, P. (1991). Mathematics methods. A resource book for primary school teachers. Malaysia: MacMillan Education Ltd.

National Council of Teachers of Mathematics (NCTM) (2000). Standarts for School Mathematics. Reston, VA: NCTM.

Neria, D., \& Amit, M. (2004). Students preference of non-algebraic representations in mathematical communication. Proceedings of the 28th Conference of the International Group for the Psychology of Mathematics Education (Vol. 3, pp. 409-416).

Orhun, N. (2007). Kesir işlemlerinde formal aritmetik ve görselleştirme arasindaki bilişsel boşluk. Inönü Üniversitesi Eğitim Fakültesi Dergisi, 8(13), 99-111.

Owens, K., \& Clements, M. A. (1998). Representations used in spatial problem solving in the classroom. Journal of Mathematical Behavior, 17(2), 197-218.

Pape, S. J., \& Tchoshanov, M. A. (2001). The role of representation(s) in developing mathematical understanding. Theory into Practice, 40(2).

Pesen, C. (2008). Kesirlerin sayı doğrusunda gösterilmesinde öğrencilerin öğrenme güçlükleri ve kavram 
yanılgıları. Inönü Üniversitesi Eğitim Fakültesi Dergisi, 9(15), 157-168.

Piaget, J., \& Cook, M. (1952). The origins of intelligence in children (Vol. 8, No. 5, p. 18). New York: International Universities Press.

Pitts, V. R. (2003). Representations of functions: An examination of pre-service mathematics teachers' knowledge of translations between algebraic and graphical representations (Unpublished PhD Dissertation). Pittsburg: University of Pittsburg.

Resnick, L. B., \& Ford, W. W. (1981). The Psychology of Mathematics for Instruction. Lawrence Erlbaum Associates.

Sert, Ö. (2007). Eighth grade students' skills in translating among different representations of algebraic concepts (Yüksek Lisans Tezi) Middle East Technical University, Ankara.

Şiap, i., \& Duru, A. (2004). Kesirlerde geometriksel modelleri kullanabilme becerisi. Gazi Üniversitesi Kastamonu Eğitim Dergisi, 12(1), 89-96.

Smith, J. P. 2002. The development of students' knowledge of fractions and ratios. In B. Litwiller, and G. Bright (Eds), Making sense of fractions, ratios, and proportions, (pp.3-17). Reston, VA: National Council of Teachers of Mathematics.

Soylu, Y., \& Soylu, C. (2005). İlköğretim beşinci sinif öğrencilerinin kesirler konusundaki öğrenme güçlükleri: Kesirlerde sıralama, toplama, çikarma, çarpma ve kesirlerle ilgili problemler. Erzincan Eğitim Fakültesi Dergisi. 7(2), 101-117.

Stickles, P. R. (2006). An analysis of secondary and middle school teachers' mathematical problem posing (Unpublished doctoral dissertation). University of Indiana, Bloomington.

Şiap, I.., \& Duru (2004). A. Kesirlerde Geometrik Modelleri Kullanabilme Becerisi. Kastamonu Eğitim Dergisi, 12(1), 89-96.

Toluk-Uçar, Z. (2009). Developing pre-service teachers understanding of fractions through problem posing. Teaching and Teacher Education, 25, 166-175.

Tunç-Pekkan, Z. (2015). An analysis of elementary school children's fractional knowledge depicted with circle, rectangle, and number line representations. Educational Studies in Mathematics, 89(3), 419-441.

Van de Walle, J. A., Karp, K. S., \& Bay-Williams, J. M. (2010). Elementary and middle school mathematics: Teaching developmentally. Boston, MA: Allyn \& Bacon.

Van der Meij, J., \& De Jong, T. (2006). Supporting students' learning with multiple representations in a dynamic simulation-based learning environment. Learning and Instruction, 16(3), 199-212.

Vergnaud, G. (1988). Multiplicative structures. In J. Hiebert and M. Behr, Number concept and operations in the middle grades (pp. 141-161). Lawrence Erlbaum Associates, Hillsdale NJ Acquisition of mathematics concepts and processes, 127-174.

Vinner, S., Hershkowitz, R., \& Bruckheimer, M. (1981).
Some cognitive factors as causes of mistakes in the addition of fractions. Journal for Research in Mathematics Education, 12, 70-76.

Wearne-Hiebert, D. C., \& Hiebert, J. (1983). Junior high school students' understanding of fractions. School Science and Mathematics, 83(2), 96-106.

Yıldırım, A., \& Şimşek, H. (2013). Sosyal bilimlerde nitel araştırma yöntemleri. Ankara: Seçkin Yayıncılık. 


\section{Appendix}

\section{Multiple Representations In Fraction Operations Test}

This test consists of 8 questions. There are 3 sub-questions in each question. Please answer carefully.

\section{Activities}

1) Perform the operation given below and answer the questions $a, b, c$ accordingly.
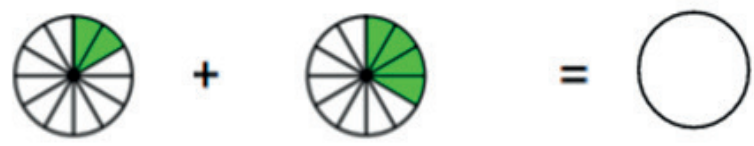
a) Perform this operation using numerals.
b) Perform this operation on the number line.
c) Pose a problem related to this operation.

2) Perform the operation given below and answer the questions $a$, b and c accordingly.

\section{$\frac{1}{4}+\frac{3}{8}=$}

a) Perform this operation on the number line.

b) Perform this operation using a model.

c) Pose a problem related to this operation.

3) Perform the operation given below and answer the questions a, b, c accordingly.

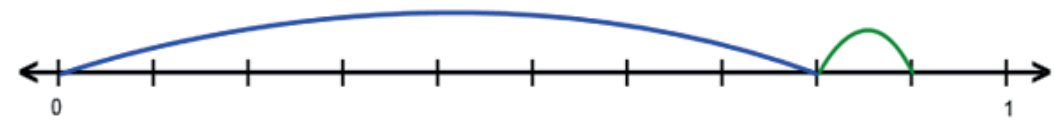

a) Perform this operation using numerals.

b) Perform this operation using a model.

c) Pose a problem related to this operation.

4) "Ezgi read three tenths of her story book first, and then two tenths." So, how many of the book did Ezgi read?" Express the problem given in this text verbally and solve it, and answer the questions in a, b, c accordingly.

a) Perform this operation on the number line.

b) Perform this operation using model representation.

c) Perform this operation using numerals.

5) Perform the operation given below and answer the questions a, b, c accordingly.

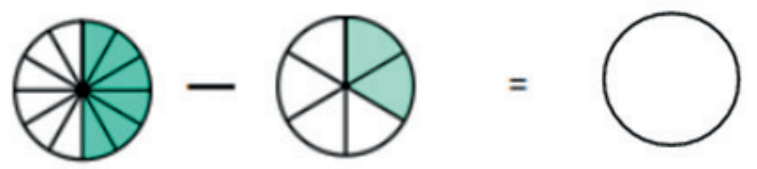
a) Perform this operation using numerals.
b) Perform this operation on the number line.
c) Pose a problem related to this operation.

6) Perform the operation given below and answer the questions a, b, c accordingly.

\section{$\frac{5}{6}-\frac{1}{3}=$}

a) Perform this operation on the number line.

b) Perform this operation using a model.

c) Pose a problem related to this operation.

7) Perform the operation given below and answer the questions a, b, c accordingly.

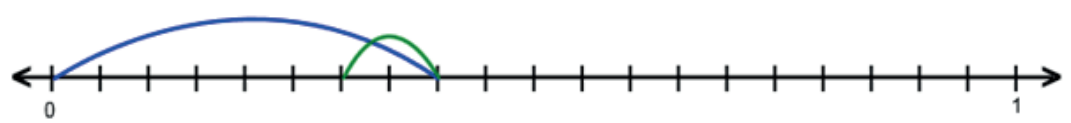

a) Perform this operation using numerals.

b) Perform this operation using a model.

c) Pose a problem related to this question. 
8) "How many more pizza did Ahmet, who ate one half, ate compared to Zeynep, who ate one fourth of the pizza?" Express the problem given in this text verbally and solve it, and answer the questions in a, b, c accordingly.
a) Perform this operation on the number line.
b) Perform this operation using a model.
c) Perform this operation using numerals. 